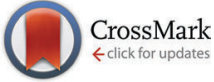

Cite this: J. Mater. Chem. B, 2016, 4, 4839

Received 21st March 2016, Accepted 13th June 2016

DOI: $10.1039 / c 6 t b 00723 f$

www.rsc.org/MaterialsB

\section{Cellular internalisation, bioimaging and dark and photodynamic cytotoxicity of silica nanoparticles doped by $\left\{\mathrm{Mo}_{6} \mathrm{I}_{8}\right\}^{4+}$ metal clusters $\dagger$}

\author{
Anastasiya O. Solovieva, ${ }^{a}$ Yuri A. Vorotnikov, ${ }^{b}$ Kristina E. Trifonova, ${ }^{a}$ \\ Olga A. Efremova, ${ }^{c}$ Anna A. Krasilnikova, ${ }^{a}$ Konstantin A. Brylev, ${ }^{\text {bd }}$ \\ Elena V. Vorontsova, ${ }^{e}$ Pavel A. Avrorov, ${ }^{f}$ Lidiya V. Shestopalova, ${ }^{d}$ \\ Alexander F. Poveshchenko, ${ }^{a}$ Yuri V. Mironov ${ }^{\text {bd }}$ and Michael A. Shestopalov ${ }^{\star a b d}$
}

\begin{abstract}
Silica nanoparticles (SNPs) doped by hexanuclear molybdenum cluster complexes $\left[\left\{\mathrm{Mo}_{6} \mathrm{X}_{8}\right\} \mathrm{L}_{6}\right]^{n}(\mathrm{X}=\mathrm{Cl}, \mathrm{Br}$, or $\mathrm{I}$; $L$ = various inorganic or organic ligands) have been recently suggested as materials with high potential for biomedical applications due to both their outstanding photoluminescence properties and their ability to efficiently generate singlet oxygen upon photoirradiation. However, no studies were undertaken so far to prove this concept. Therefore, here we examined the potential of photoluminescent SNPs doped by $\left\{\mathrm{Mo}_{6} \mathrm{I}_{8}\right\}^{4+}$ for applications such as bioimaging and photodynamic therapy using the human epidermoid larynx carcinoma (Hep-2) cell line as a model. Our results demonstrated both: (i) significant luminescence from cells with internalised molybdenum cluster-doped SNPs combined with the low cytotoxicity of particles in the darkness and (ii) significant cytotoxicity of the particles upon photoirradiation. Thus, this research provides strong experimental evidence for high potential of molybdenum-cluster-doped materials in biomedical applications such as optical bioimaging, biolabeling and photodynamic therapy.
\end{abstract}

\section{Introduction}

Hexanuclear molybdenum cluster complexes with the general formula $\left[\left\{\mathrm{Mo}_{6} \mathrm{X}_{8}\right\} \mathrm{L}_{6}\right]^{n}(\mathrm{X}=\mathrm{Cl}, \mathrm{Br}$, or $\mathrm{I}$; $\mathrm{L}=$ various inorganic or organic ligands) (Fig. 1) have recently attracted significant interest in the context of application in biomedical technologies. ${ }^{1-3}$

This is due to an outstanding balance of physical and chemical properties that these materials offer. Firstly, similar to their structural analogues, hexarhenium clusters $\left[\left\{\mathrm{Re}_{6} \mathrm{Q}_{8}\right\} \mathrm{L}_{6}\right]^{m}$ $(\mathrm{Q}=\mathrm{S}$ or $\mathrm{Se})$, these complexes demonstrate high chemical and photostability of the cluster cores $\left\{\mathrm{Mo}_{6} \mathrm{X}_{8}\right\}^{4+}$ that are primarily

\footnotetext{
${ }^{a}$ Scientific Institute of Clinical and Experimental Lymphology, 2 Timakova st., 630060 Novosibirsk, Russian Federation

${ }^{b}$ Nikolaev Institute of Inorganic Chemistry SB RAS, 3 Acad. Lavrentiev ave., 630090 Novosibirsk, Russian Federation. E-mail: shtopy@niic.nsc.ru 'Department of Chemistry, University of Hull, Cottingham Road, HU6 7RX, Hull, UK

${ }^{d}$ Novosibirsk State University, 2 Pirogovast., 630090 Novosibirsk, Russian Federation

${ }^{e}$ The Institute of Molecular Biology and Biophysics, 2/12 Timakova st., 630117 Novosibirsk, Russian Federation

${ }^{f}$ Scientific Research Institute of Physiology and Basic Medicine, 4 Timakova st., 630117 Novosibirsk, Russia Federation

$\dagger$ Electronic supplementary information (ESI) available: DLS, FTIR, excitation and emission spectra and TEM and confocal laser scanning microscopy images. See DOI: $10.1039 /$ c6tb00723f
}

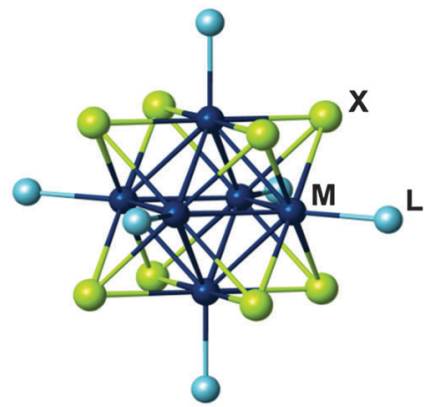

Fig. 1 Representation of the $\left[\left\{\mathrm{Mo}_{6} \mathrm{X}_{8}\right\} \mathrm{L}_{6}\right]^{n}$ cluster complex.

responsible for their triplet excited state photoluminescence (i.e. phosphorescence). Secondly, their broad emission spectra extend in the red/near infra-red region (from $\sim 550$ to more than $950 \mathrm{~nm})^{4-13}$ overlapping the so-called "optical tissue window" (650-900 nm), where the boundaries of the region are defined by the minimal light absorption of hemoglobin $(<650 \mathrm{~nm})$ and water $(>900 \mathrm{~nm}){ }^{14}$ Thirdly, such complexes are characterised by impressive photoluminescence quantum yields (PLQYs) for inorganic compounds. ${ }^{4,5,11,15}$ Additionally, the metal cluster complexes can also act as powerful photosensitisers in the singlet oxygen $\left({ }^{1} \mathrm{O}_{2}\right)$ generation, ${ }^{5-8,16-18}$ which 
makes them especially interesting for applications associated with the generation of singlet oxygen in vivo, such as, for example, photodynamic therapy (PDT) ${ }^{19-22}$ Fourthly, the cluster complexes are inherently highly electron dense and therefore can be used as contrast agents in transmission electron microscopy (TEM) and X-Ray imaging. ${ }^{23}$ Finally, the low toxicity of the molybdenum octahedral cluster complexes and derived materials was evidenced by different research groups. ${ }^{24-26}$

All together these properties make hexamolybdenum cluster complexes very attractive for biomedical applications (e.g. biolabeling and diagnostic bioimaging), and therapeutic (PDT agents) and even combined diagnostic and therapeutic (theranostic) applications. ${ }^{27}$

Despite the mentioned potential for biomedical applications, the known hexamolybdenum cluster complexes themselves are not ideally suited for these purposes. Most of them are either insoluble in water or, after being dissolved in water, they hydrolyse forming insoluble products. Both the poor water solubility and the susceptibility to hydrolysis hinder the application of molybdenum metal cluster complexes within a physiological environment.

The necessary water solubility could be achieved by the ligation of the $\left\{\mathrm{Mo}_{6} \mathrm{X}_{8}\right\}^{4+}$-cluster core with hydrophilic ligands, by analogy with hexarhenium cluster complexes. ${ }^{23,28-33}$ Indeed, this approach was successfully realised with the use of inorganic hydrophilic ligands $\mathrm{NCS}^{-}$and $\mathrm{N}_{3}{ }^{-} \cdot{ }^{25,30}$ However, these ligands do not protect the molybdenum cluster from the hydrolysis. To avoid the possible exchange of the ligands $\mathrm{L}$ by water molecules or $\mathrm{OH}^{-}$ions and simultaneously achieve biocompatibility, the molybdenum metal cluster complex can be encapsulated within an inert biocompatible carrier matrix, such as polystyrene (PS) micro-beads ${ }^{11,18,26}$ or $\mathrm{SiO}_{2} \cdot{ }^{5,24,34,35}$ Despite the significant progress made in the development of PS and $\mathrm{SiO}_{2}$ supported metal cluster complexes, biological properties were not sufficiently studied for any of the above materials apart from the cytotoxicity of $\left\{\mathrm{Mo}_{6} \mathrm{I}_{8}\right\} @ P S-\mathrm{SH}$, which demonstrated low toxicity to Hep-2 human epidermoid larynx carcinoma, ${ }^{26}$ and $\mathrm{Cs}_{2}\left[\left\{\mathrm{Mo}_{6} \mathrm{Br}_{8}\right\} \mathrm{Br}_{6}\right] @ \mathrm{SiO}_{2}$, which showed moderate toxicity to Caco-2 gut epithelial cells and MRC-5 lung fibroblasts. ${ }^{24}$

To fill this lapse, we selected silica nanoparticles (SNPs) of two different compositions $-\left\{\mathrm{Mo}_{6} \mathrm{I}_{8}\right\}^{0.001} @ \mathrm{SiO}_{2}$ and $\left\{\mathrm{Mo}_{6} \mathrm{I}_{8}\right\}^{0.01} @ \mathrm{SiO}_{2}$ (Fig. 2 and Fig. S1-S3, ESI $\dagger$ ) - prepared according to an earlier described method from $\left[\left\{\mathrm{Mo}_{6} \mathrm{I}_{8}\right\}\left(\mathrm{NO}_{3}\right)_{6}\right]^{2-}$ bearing labile nitrato ligands as a convenient source of $\left\{\mathrm{Mo}_{6} \mathrm{I}_{8}\right\}{ }^{4+} \cdot{ }^{35}$ Although the cluster loading in the particles is quite low, the particles demonstrate decent PLQY values ( 0.12 and 0.03 , respectively) and relatively good efficiencies of singlet oxygen generation. ${ }^{35}$ The particles

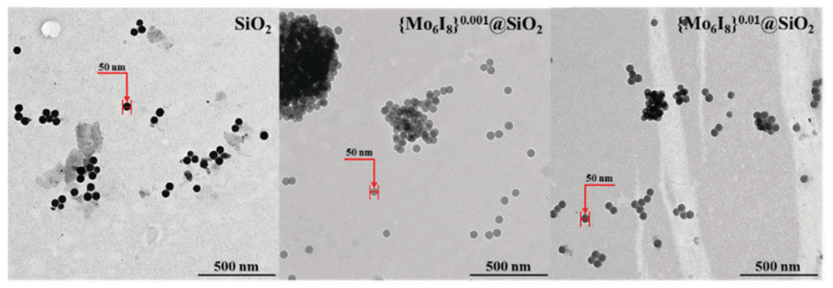

Fig. 2 TEM images of neat $\mathrm{SiO}_{2}$ and $\left\{\mathrm{Mo}_{6} \mathrm{I}_{8}\right\} \mathrm{aSiO}_{2} \mathrm{NPs}$. also have an optimal size of $50 \mathrm{~nm}$ and shape for biological studies. ${ }^{36-39}$ In order to evaluate the potential of $\left\{\mathrm{Mo}_{6} \mathrm{I}_{8}\right\} @ \mathrm{SiO}_{2}$ for bioimaging and/or photodynamic activity, we studied their ability to be internalised into Hep-2 cells, cellular distribution and cellular efflux degree and bench-marked them against similar neat $\mathrm{SiO}_{2}$ particles. ${ }^{40}$ We also studied the toxicity of $\left\{\mathrm{Mo}_{6} \mathrm{I}_{8}\right\} @ \mathrm{SiO}_{2}$ for Hep-2 cells in the darkness and upon light irradiation.

\section{Results and discussion}

\section{Cell viability and proliferation of SNPs}

The effect of neat $\mathrm{SiO}_{2},\left\{\mathrm{Mo}_{6} \mathrm{I}_{8}\right\}^{0.001} @ \mathrm{SiO}_{2}$ and $\left\{\mathrm{Mo}_{6} \mathrm{I}_{8}\right\}^{0.01} @ \mathrm{SiO}_{2}$ nanoparticles on viability of Hep-2 cells was evaluated by the MTT assay. ${ }^{41}$ The percentage of the metabolically active cells was determined against the negative control. It was shown that SNPs in the concentration range from 0.0015 to $0.375 \mathrm{mg} \mathrm{mL}^{-1}$ did not influence the viability of the cells. However, the increase of concentration of all types of SNPs above $0.75 \mathrm{mg} \mathrm{mL}^{-1}$ caused a slight reduction of the number of metabolically active cells down to $80 \%$ (Fig. 3).

We also studied the influence of SNPs on the viability and proliferation of Hep-2 cells and their apoptosis degree using dual staining with Hoechst 33342/propidium iodide (PI). A representative fluorescence microscopy image of cells (Fig. 4) shows the morphological changes of the Hep-2 cells. We found that the treatment of the cells with 0.02 to $0.18 \mathrm{mg} \mathrm{mL}^{-1}$ of cluster-doped SNPs affected neither cell density nor cell viability (Fig. 5). This finding agrees well with the data of the MTT assay. However, we observed that treatment of cells with $\left\{\mathrm{Mo}_{6} \mathrm{I}_{8}\right\} @ \mathrm{SiO}_{2}$ nanoparticles taken in the concentration range of $0.375-1.5 \mathrm{mg} \mathrm{mL}^{-1}$ led to a decrease of the cell density. The usable concentrations of $\left\{\mathrm{Mo}_{6} \mathrm{I}_{8}\right\} @ \mathrm{SiO}_{2}$ for practical biomedical applications are thus recommended to not exceed $0.18 \mathrm{mg} \mathrm{mL}^{-1}$.

\section{Cellular uptake and elimination kinetics}

The quantitative analyses of the cellular uptake and elimination kinetics of SNPs were carried out using flow cytometry (FACS). The Hep-2 cells were treated with $\left\{\mathrm{Mo}_{6} \mathrm{I}_{8}\right\} @ \mathrm{SiO}_{2}$ nanoparticles at a concentration of $0.1 \mathrm{mg} \mathrm{mL} \mathrm{m}^{-1}$. According to FACS data, the

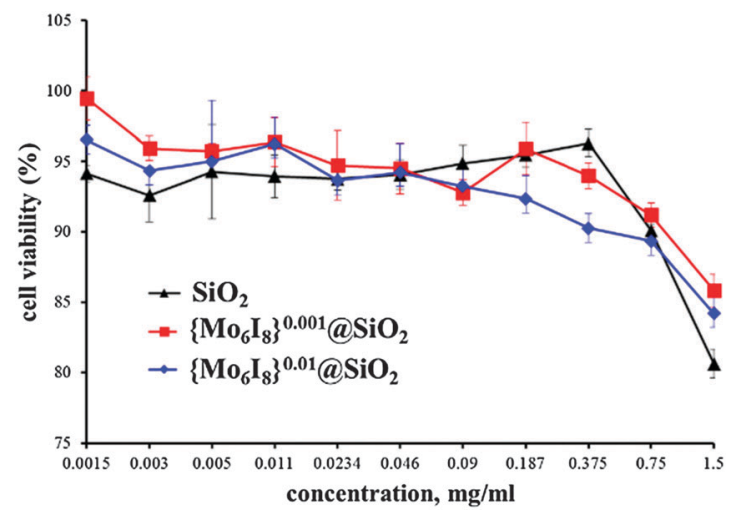

Fig. 3 Viability of Hep-2 cells incubated with neat $\mathrm{SiO}_{2}$ and $\left\{\mathrm{Mo}_{6} \mathrm{I}_{8}\right\} \mathrm{aSiO}_{2}$ NPs determined by MTT assay. 


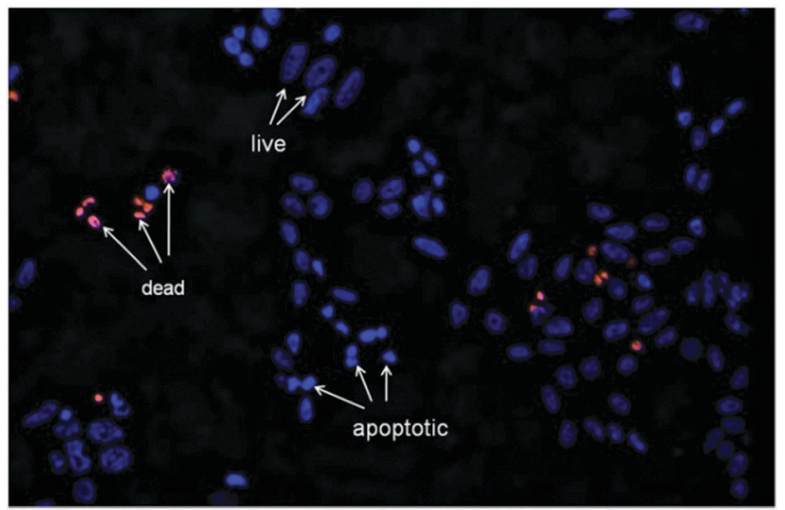

Fig. 4 Representative image that shows the morphological changes of Hep-2 cells after incubation with $\left\{\mathrm{Mo}_{6} \mathrm{I}_{8}\right\}^{0.001} \mathrm{aSiO}_{2}\left(1.5 \mathrm{mg} \mathrm{mL}{ }^{-1}\right)$, as detected by dual staining by Hoechst 33342/PI.

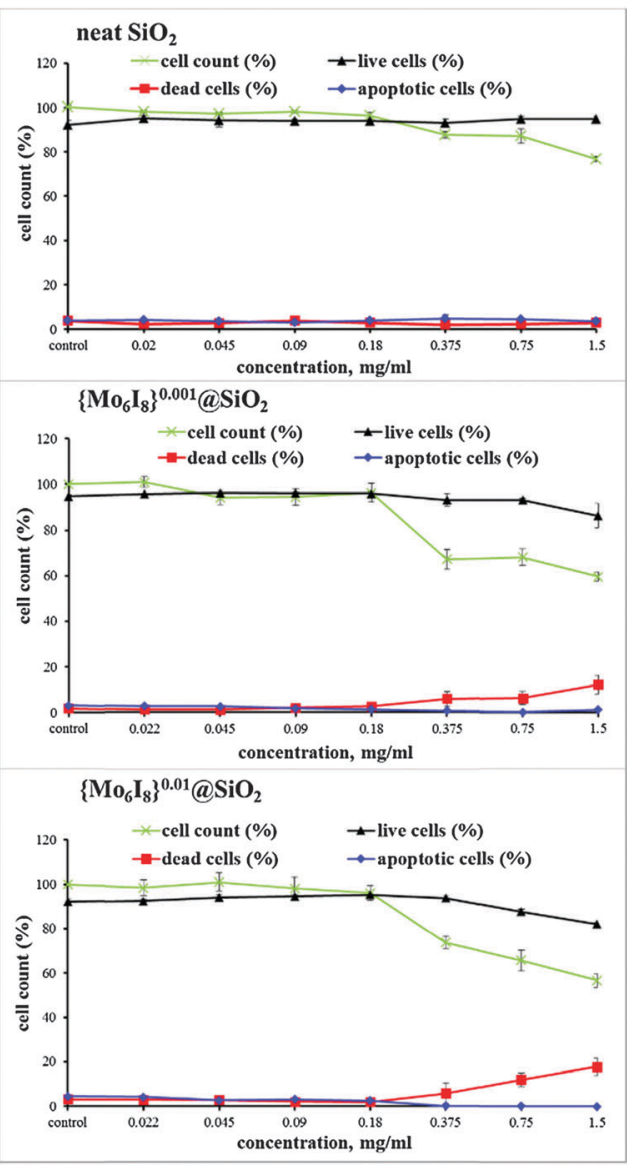

Fig. 5 Effect of neat $\mathrm{SiO}_{2}$ and $\left\{\left.\mathrm{Mo}_{6}\right|_{8}\right\} \mathrm{aSiO}_{2} \mathrm{NPs}$ on the viability and proliferation of Hep-2 cells determined by dual staining with Hoechst 33342/PI.

luminescence intensity of the treated cells was found to be much higher than that of the untreated control cells. To determine the kinetics of $\left\{\mathrm{Mo}_{6} \mathrm{I}_{8}\right\} @ \mathrm{SiO}_{2}$ uptake by the cells we plotted the mean photoluminescence intensity of the cells $v s$. the incubation time (Fig. 6A). Maximal cellular uptake of both types of photoluminescent SNPs was observed after $2 \mathrm{~h}$ of incubation, after which it

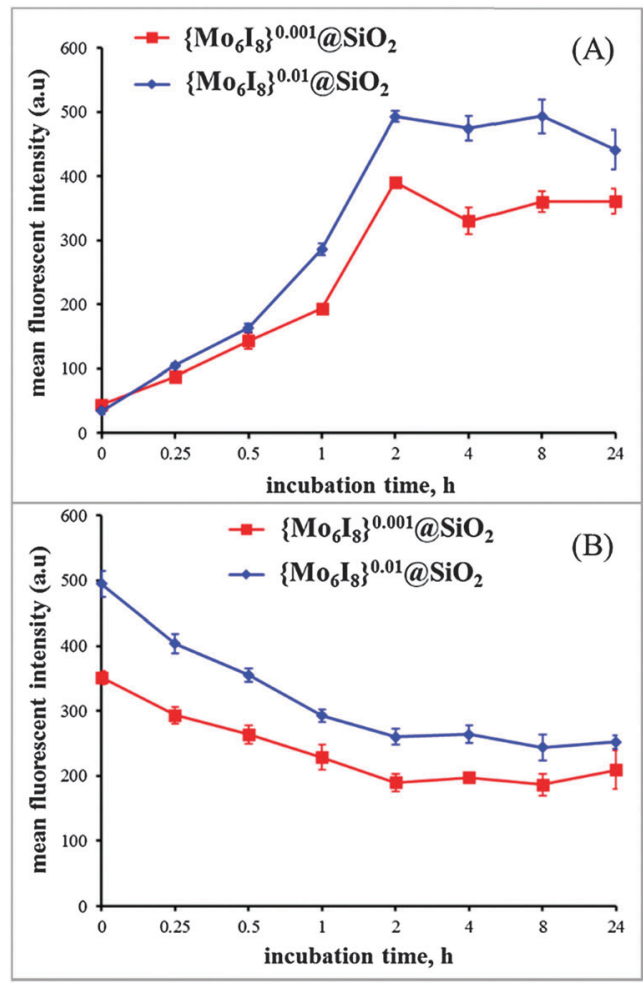

Fig. 6 (A) Kinetics of $\left\{\mathrm{Mo}_{6} \mathrm{I}_{8}\right\} \mathrm{aSiO}_{2} \mathrm{NP}$ uptake by Hep-2 cells. (B) Cellular elimination kinetics of $\left\{\mathrm{Mo}_{6} \mathrm{I}_{8}\right\} \mathrm{QSiO}_{2} \mathrm{NPs}$.

plateaued and did not significantly change for up to $24 \mathrm{~h}$. Since the maximal accumulation of SNPs occurred after $2 \mathrm{~h}$ of incubation, the study of $\left\{\mathrm{Mo}_{6} \mathrm{I}_{8}\right\} @ \mathrm{SiO}_{2}$ cellular elimination kinetics was performed on the cells incubated for this period of time (Fig. 6B). It was shown that SNPs are actively excreted during the first $2 \mathrm{~h}$, after that the photoluminescence intensity of the incubated cells did not significantly change and remained at a high level thereafter. Thus, our findings suggest both that SNPs rapidly enter the cells and remain there for a long time and that the loading of the metal cluster in SNPs does not affect the rate of internalisation and efflux of the particles.

\section{Cellular internalisation and intracellular distribution}

While FACS provides valuable quantitative data of the uptake and efflux, it however lacks the ability to determine the intracellular distribution of the particles. In order to determine the cellular distribution of $\left\{\mathrm{Mo}_{6} \mathrm{I}_{8}\right\} @ \mathrm{SiO}_{2}$ nanoparticles we visualised the cells by confocal microscopy and TEM. Upon confocal microscopy imaging of the treated cells $\left(\lambda_{\mathrm{ex}}=405 \mathrm{~nm}\right)$ we indeed observed the intense red photoluminescence located in the cells (Fig. 7 and Fig. S4, ESI $\dagger$ ). Moreover, Z-stack analysis (Fig. S5, ESI $\dagger$ ) clearly showed that the fluorescence intensity is located inside the cells, confirming that SNPs entered the cells and were not just adherent on the cell surface. Specifically, confocal microscopy revealed that localisation of SNPs was in the cell cytoplasm, on the periphery of the cell and in the space near the nuclei.

TEM imaging of the cells incubated with SNPs under identical conditions as for confocal microscopy assay gave us even more 


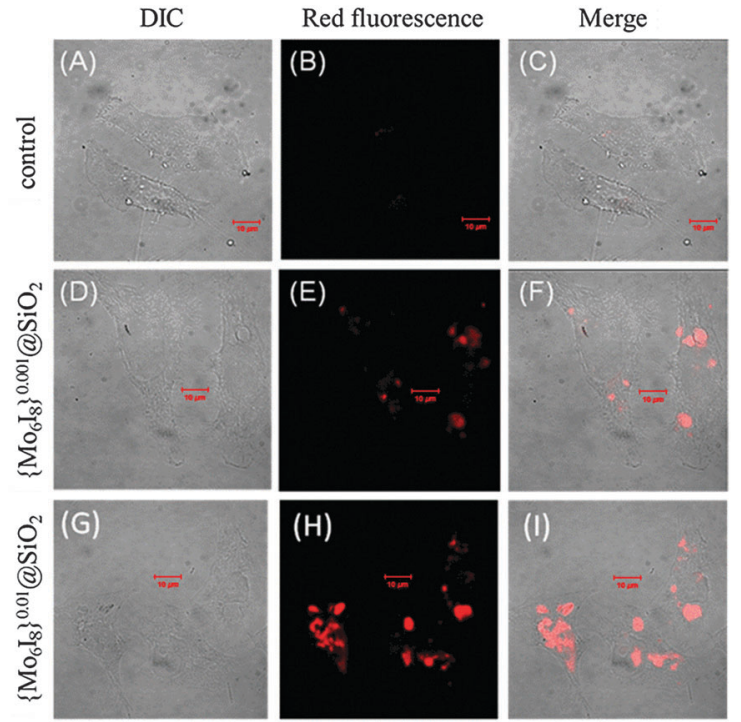

Fig. 7 Cellular uptake of cluster-doped SNPs by confocal fluorescence microscopy. Differential interference contrast (DIC) (A, D and G), red fluorescence (B, E and $\mathrm{H})$, and merged images (,$F$ and $\mathrm{I})$.

details on localisation of the particles within the Hep-2 cells and also some initial ideas about the possible cellular uptake mechanisms. TEM images did not show any signs of abnormal changes of the cell ultrastructure. We also observed no difference in the intracellular distribution between neat $\mathrm{SiO}_{2},\left\{\mathrm{Mo}_{6} \mathrm{I}_{8}\right\}^{0.001} @ \mathrm{SiO}_{2}$ and $\left\{\mathrm{Mo}_{6} \mathrm{I}_{8}\right\}^{0.01} @ \mathrm{SiO}_{2}$. TEM images showed that SNPs were mostly located within membrane-enclosed vesicles of different sizes, i.e. endosomes (Fig. 8, Fig. S6 and S7, ESI†). Also zetapotential measurements of neat $\mathrm{SiO}_{2},\left\{\mathrm{Mo}_{6} \mathrm{I}_{8}\right\}^{0.001} @ \mathrm{SiO}_{2}$ and $\left\{\mathrm{Mo}_{6} \mathrm{I}_{8}\right\}^{0.01} @ \mathrm{SiO}_{2}$ showed that they all had negative charges with the corresponding values of $-23 \pm 2 \mathrm{mV},-40 \pm 1 \mathrm{mV}$, and $-21 \pm 1 \mathrm{mV}$. These supported the general assumption that silica particles entered the cells by the endocytosis mechanism. ${ }^{42,43}$ However, alternative mechanisms such as, for example, uptake with the extracellular fluid by micropinocytosis are also possible. ${ }^{44}$ In some cases, we also observed free SNPs in the cytosol that could be due to some mechanism of endosomal escape. We also observed free SNPs localised in the cytosol near the nucleus. Such localisation may cause stronger effects of SNPs directly on the nucleus (for example, upon photoirradiation), even if SNPs themselves do not enter the nucleus.

Therefore, exact mechanisms of cellular uptake and efflux still need to be determined to fully evaluate potential of SNPs for biomedical applications.

\section{In vitro photodynamic toxicity}

Having established that molybdenum cluster-doped SNPs can easily enter the cells and remain within for sufficiently a long time and also that they show low toxicity in the darkness, we were keen to examine whether these SNPs could be used as a tool for intercellular photosensitisation. To do that we first confirmed the generation of singlet oxygen by the SNPs after photoirradiation in Hep-2 cells (Fig. S9, ESI $\dagger$ ) and then the photodynamic

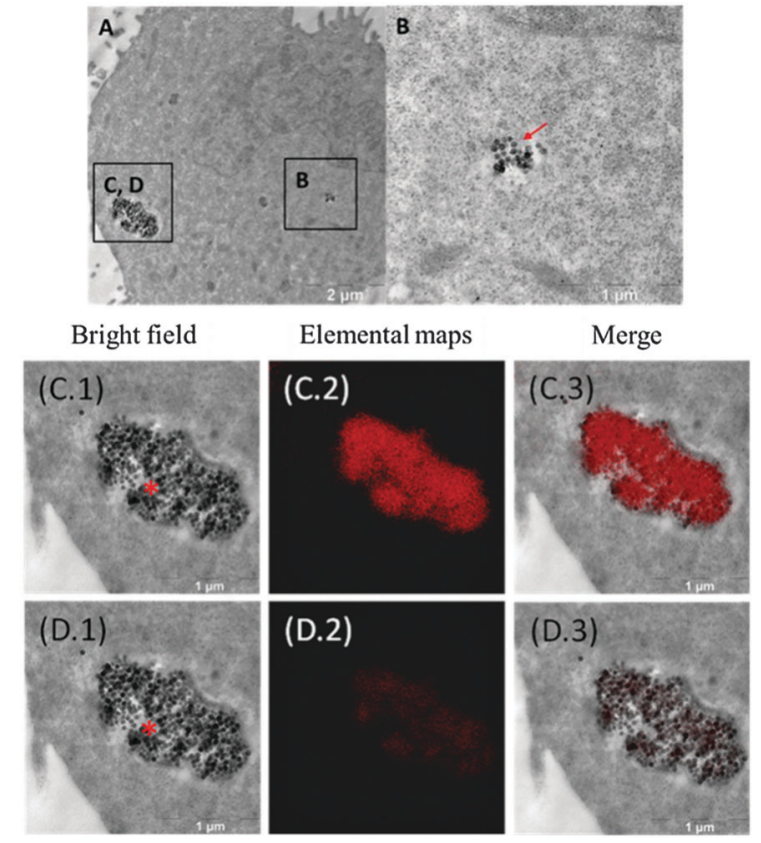

Fig. 8 TEM image of a Hep-2 cell after incubation with $0.1 \mathrm{mg} \mathrm{mL}^{-1}$ of $\left\{\mathrm{Mo}_{6} \mathrm{I}_{8}\right\}^{0.001} \mathrm{aSiO}_{2}$ for 24 hours at $37^{\circ} \mathrm{C}$. (A) General view of the Hep-2 cell. (B)-(D) Higher magnification image of the area indicated by the box B-D in A, respectively. SNPs in the endosome are indicated by the asterisk, and free SNPs in cytoplasm are indicated by the arrow. (C.1) and (D.1) higher magnification bright field image of the area indicated by the box $C$ and $D$ in the image A. (C.2) Si L2,3-edge, EF-TEM elemental map shows concentrated regions of silicon and (D.2) Mo L2,3-edge, EF-TEM elemental map shows concentrated regions of molybdenum. (C.3) and (D.3) demonstrate the localisation of SNPs in the cell. Similarity between elemental maps for $\mathrm{Si}$ (C.2) and Mo (D.2) confirms that we visualised $\left.\left\{\mathrm{Mo}_{6}\right\}_{8}\right\}^{0.001} \mathrm{aSiO}_{2}$ nanoparticles.

toxicity was studied. Hep-2 cells were treated with neat $\mathrm{SiO}_{2}$, $\left\{\mathrm{Mo}_{6} \mathrm{I}_{8}\right\}^{0.001} @ \mathrm{SiO}_{2}$ and $\left\{\mathrm{Mo}_{6} \mathrm{I}_{8}\right\}^{0.01} @ \mathrm{SiO}_{2}$ in concentrations from 0.0125 to $0.22 \mathrm{mg} \mathrm{mL} \mathrm{m}^{-1}$, i.e. in the range where both neat and doped SNPs did not show any cellular toxicity in the darkness as it was shown by cytotoxicity assay (Fig. 3). As a positive control, Hep-2 cells were also treated with the second-generation commercial photosensitiser Radachlorin at concentrations typical for in vitro experiments. ${ }^{45}$ Both treated cells and untreated negative control cells were then irradiated by light with $\lambda \geq 400 \mathrm{~nm}$ and evaluated using viability, apoptosis and proliferation assay.

The microscopy images (Fig. 9 and Fig. S8, ESI $\dagger$ ) clearly showed that Hep-2 cells in groups without irradiation and in the negative control group and $\mathrm{SiO}_{2}$ after irradiation had a spindle shape, were in close contact with neighbouring cells and adhered to the surface of the culture flask. The images have also shown that Hep-2 cells treated with cluster-doped SNPs in concentrations above $0.18 \mathrm{mg} \mathrm{mL}{ }^{-1}$ became condensed and rounded after light irradiation (Fig. S8 (B.7-B.9), ESI†).

The effect of concentration of the photosensitisers on the cells is demonstrated in Fig. 10. Namely, the graphs show that the number of apoptotic cells was the highest after the Hep-2 cells were treated with $0.0125-0.05 \mathrm{mg} \mathrm{mL}{ }^{-1}$ of $\left\{\mathrm{Mo}_{6} \mathrm{I}_{8}\right\}^{0.001} @ \mathrm{SiO}_{2}$, $0.05 \mathrm{mg} \mathrm{mL}{ }^{-1}$ of $\left\{\mathrm{Mo}_{6} \mathrm{I}_{8}\right\}^{0.01} @ \mathrm{SiO}_{2}$ and $0.01525 \mathrm{mg} \mathrm{mL}{ }^{-1}$ of 

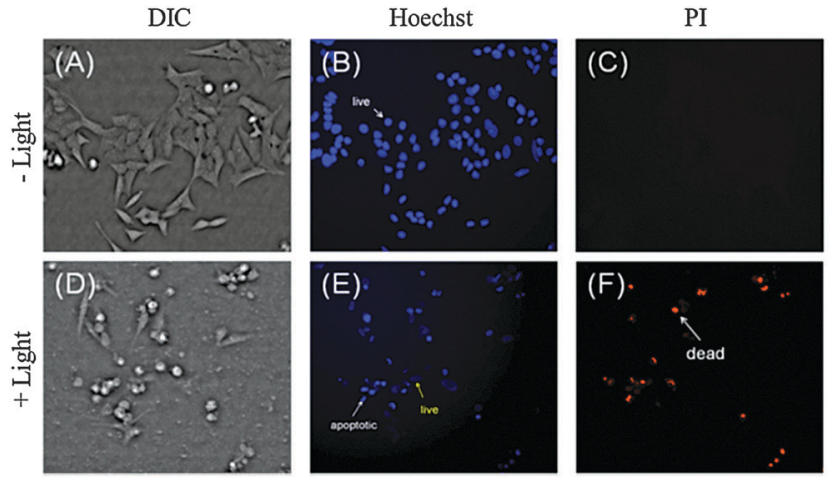

Fig. 9 Effect of $\left\{\mathrm{Mo}_{6} \mathrm{I}_{8}\right\}^{0.01} \mathrm{aSiO}_{2}\left(0.1 \mathrm{mg} \mathrm{mL}{ }^{-1}\right)$ on Hep-2 cells before (top) and after (bottom) photoirradiation determined by dual staining with Hoechst 33342/PI.

Radachlorin. Moreover, the number of dead cells clearly increased in the samples treated with $\left\{\mathrm{Mo}_{6} \mathrm{I}_{8}\right\}^{0.001} @ \mathrm{SiO}_{2}$ in the concentrations above $0.18 \mathrm{mg} \mathrm{mL}{ }^{-1}$, with $\left\{\mathrm{Mo}_{6} \mathrm{I}_{8}\right\}^{0.01} @ \mathrm{SiO}_{2}$ in the concentrations above $0.025 \mathrm{mg} \mathrm{mL}^{-1}$ and Radachlorin in the concentrations above $0.01525 \mathrm{mg} \mathrm{mL}^{-1}$ (Fig. 10 and Fig. S8(B), $\mathrm{ESI} \dagger$ ).

We were also able to determine $\mathrm{IC}_{50}$ for $\left\{\mathrm{Mo}_{6} \mathrm{I}_{8}\right\}^{0.01} @ \mathrm{SiO}_{2}$ and Radachlorin under light irradiation $\left(0.075 \pm 0.007 \mathrm{mg} \mathrm{mL}^{-1}\right.$ and $0.021 \pm 0.002 \mathrm{mg} \mathrm{mL}^{-1}$, respectively), while we detected only $\sim 35 \%$ of dead cells in culture samples treated with $\left\{\mathrm{Mo}_{6} \mathrm{I}_{8}\right\}^{0.001} @ \mathrm{SiO}_{2}$ taken at a concentration of $0.22 \mathrm{mg} \mathrm{mL}{ }^{-1}$. Thus, SNPs with the higher loading of the metal cluster demonstrated the stronger photodynamic cytotoxicity. This photodynamic cytotoxicity is of the same order of magnitude as a currently available photosensitiser Radochlorin, which was previously used for fluorescence diagnosis and photodynamic therapy of malignant tumours. ${ }^{46,47}$ We believe that the photo-induced cytotoxic effect of $\left\{\mathrm{Mo}_{6} \mathrm{I}_{8}\right\}^{0.001} @ \mathrm{SiO}_{2}$ and $\left\{\mathrm{Mo}_{6} \mathrm{I}_{8}\right\}^{0.01} @ \mathrm{SiO}_{2}$ is caused mostly by free particles rather than the ones localised in endosomes, since they extend the cytotoxic effect of ROS within the cytoplasm. Moreover, there is also a possibility that the molybdenum-cluster-doped SNPs could facilitate endosomal escape. Specifically, short-living and highly reactive singlet oxygen generated by $\left\{\mathrm{Mo}_{6} \mathrm{I}_{8}\right\} @ \mathrm{SiO}_{2}$ upon photoirradiation could destroy the endosomal/lysosomal membrane and enable the contents of the organelles to be delivered to the cytosol. Indeed, some earlier works have already shown that photoactive moieties, either alone or incorporated into nanoparticles, can be used to disrupt the endosomal membrane upon exposure to light, consequently facilitating the endosomal escape. $^{48,49}$

To summarise, the viability of the untreated cells under irradiation was found to be $100 \%$. As expected, neat SNPs did not show any photoinduced cytotoxicity in the chosen range of concentrations. The irradiation of the cells treated with $\left\{\mathrm{Mo}_{6} \mathrm{I}_{8}\right\} @ \mathrm{SiO}_{2}$ demonstrated a concentration-dependent decrease in cellularity and a corresponding increase in the number of dead cells (Fig. 10). SNPs with the higher load of the metal cluster showed increased photoinduced cellular toxicity, comparable with the commercially available photosensitiser Radachlorin. To the best of our knowledge, this is the first in vitro study that
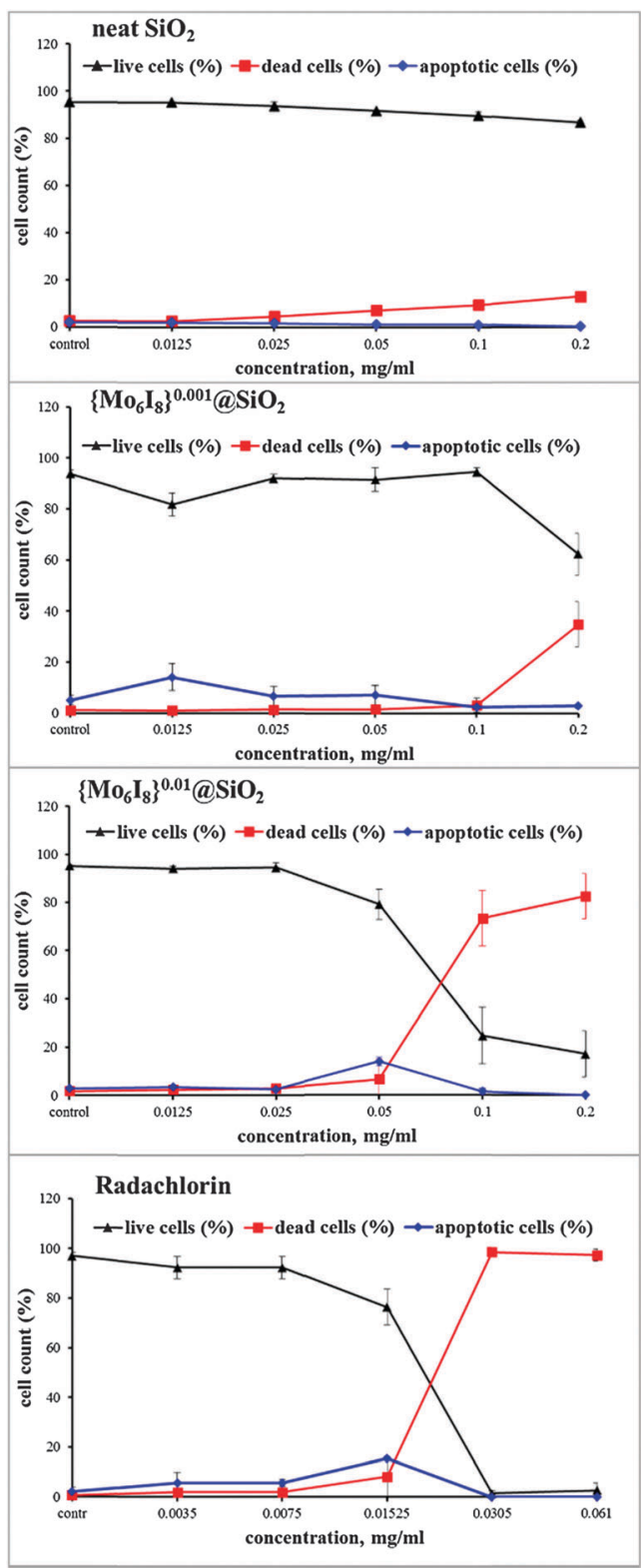

Fig. 10 Viability of Hep-2 cells treated with SNPs $\left(\mathrm{SiO}_{2},\left\{\mathrm{Mo}_{6} \mathrm{I}_{8}\right\}^{0.001} \mathrm{aSiO}_{2}\right.$ and $\left\{\mathrm{Mo}_{6} \mathrm{I}_{8}\right\}^{0.01}\left(\mathrm{aSiO}_{2}\right)$ after photoirradiation $(\lambda \geq 400 \mathrm{~nm}, 30 \mathrm{~min})$ determined by dual staining with Hoechst 33342/PI.

demonstrates the cytotoxicity of materials based on $\mathrm{Mo}_{6}$ metal clusters upon photoirradiation. This study, thus, provides the first experimental evidence of the potential of these and similar materials for applications associated with the generation of singlet oxygen in vivo, such as PDT.

\section{Experimental}

\section{Synthesis of the nanoparticles}

Nanoparticles $\left\{\mathrm{Mo}_{6} \mathrm{I}_{8}\right\}^{0.001} @ \mathrm{SiO}_{2}$ and $\left\{\mathrm{Mo}_{6} \mathrm{I}_{8}\right\}^{0.01} @ \mathrm{SiO}_{2}$ with an average particle size of $50 \mathrm{~nm}$ were synthesised according to an earlier described method. In general, $\left(\mathrm{Bu}_{4} \mathrm{~N}\right)_{2}\left[\left\{\mathrm{Mo}_{6} \mathrm{I}_{8}\right\}\left(\mathrm{NO}_{3}\right)_{6}\right]^{11}$ (1.7 or $17 \mathrm{mg}$, respectively) dissolved in ethanol $(2.5 \mathrm{~mL}$ ) was 
added to the distilled water $(2.5 \mathrm{~mL})$. To prepare a microemulsion, both the ethanol/water solution of $\left(\mathrm{Bu}_{4} \mathrm{~N}\right)_{2}\left[\left\{\mathrm{Mo}_{6} \mathrm{I}_{8}\right\}\left(\mathrm{NO}_{3}\right)_{6}\right]$ $(1.6 \mathrm{~mL})$ and $25 \%$ aqueous ammonia solution $(1.3 \mathrm{~mL})$ were added to the mixture of $n$-heptane ( $47 \mathrm{~mL}$ ) and Brij L4 surfactant (15 mL). This mixture was stirred for $30 \mathrm{~min}$ to ensure the homogeneity of the microemulsion. Finally, tetraethyl orthosilicate $(2 \mathrm{~mL}$ ) was added and the mixture was stirred for $72 \mathrm{~h}$. Thereafter, the obtained yellowish colloidal solution was centrifuged (7000 rpm for $10 \mathrm{~min}$ ), washed successively with ethanol, water and acetone and dried at $60{ }^{\circ} \mathrm{C}$ in air. $\mathrm{Neat} \mathrm{SiO}_{2}$ nanoparticles were obtained by the same method, but without $\left(\mathrm{Bu}_{4} \mathrm{~N}\right)_{2}\left[\left\{\mathrm{Mo}_{6} \mathrm{I}_{8}\right\}\left(\mathrm{NO}_{3}\right)_{6}\right]$.

\section{Cell culture}

The human larynx carcinoma cell line (Hep-2) was purchased from the State Research Center of Virology and Biotechnology VECTOR and cultured in Eagle's Minimum Essential Medium (EMEM, pH $=7.4$ ) supplemented with a $10 \%$ fetal bovine serum under a humidified atmosphere $\left(5 \% \mathrm{CO}_{2}\right.$ and $95 \%$ air $)$ at $37{ }^{\circ} \mathrm{C}$.

\section{MTT-assay}

The effect of SNPs (neat $\mathrm{SiO}_{2}, \quad\left\{\mathrm{Mo}_{6} \mathrm{I}_{8}\right\}^{0.001} @ \mathrm{SiO}_{2}$ and $\left.\left\{\mathrm{Mo}_{6} \mathrm{I}_{8}\right\}^{0.01} @ \mathrm{SiO}_{2}\right)$ on the cell metabolic activity was determined using the 3-[4,5-dimethylthiazol-2-yl]-2,5-diphenyltetrazolium bromide (MTT) colorimetric assay. The Hep-2 cells were seeded into 96-well plates at $5 \times 10^{3}$ cells per well in a medium containing SNPs with concentrations from 0.0015 to $1.5 \mathrm{mg} \mathrm{mL}^{-1}$ and then incubated for $24 \mathrm{~h}$ under a $5 \% \mathrm{CO}_{2}$ atmosphere. $10 \mu \mathrm{L}$ of the MTT solution ( $5 \mathrm{mg} \mathrm{mL}^{-1}$ ) was added to each well, the plates were incubated for $4 \mathrm{~h}$ and then the formazan formed was dissolved in DMSO $(200 \mu \mathrm{L})$. The optical density was measured using a plate reader Multiskan FC (Thermo scientific, USA) at a wavelength of $620 \mathrm{~nm}$. The experiment was repeated three times on separate days.

\section{Viability, apoptosis and proliferation assay}

Cell viability, apoptosis and proliferation were detected by Hoechst 33342/PI staining as previously described by Lee et al. ${ }^{50}$ The Hep-2 cells were seeded on 96-well plates at $5 \times 10^{3}$ cells per well in a medium containing SNPs (neat $\mathrm{SiO}_{2}$ and $\left\{\mathrm{Mo}_{6} \mathrm{I}_{8}\right\} @ \mathrm{SiO}_{2}$ ) at concentrations from $0.0015 \mathrm{mg} \mathrm{mL}^{-1}$ to $1.5 \mathrm{mg} \mathrm{mL}^{-1}$ and incubated for $24 \mathrm{~h}$. The cells incubated in the absence of SNPs were used as a control. Treated cells and control cells were stained with Hoechst 33342 (Sigma-Aldrich) for $30 \mathrm{~min}$ at $37{ }^{\circ} \mathrm{C}$ and PI (Sigma-Aldrich) for $10 \mathrm{~min}$ at $37^{\circ} \mathrm{C}$. An IN Cell Analyzer 2200 (GE Healthcare, UK) was used to perform automatic imaging of six fields per well under $200 \times$ magnification, in brightfield and fluorescence channels. The images produced were used to analyse live, apoptotic and dead cells among the whole population using the IN Cell Investigator software (GE Healthcare, UK).

\section{Cellular uptake kinetics}

Hep-2 cells were seeded in 6-well plates at $3 \times 10^{5}$ cells per well for each time point and were incubated for $24 \mathrm{~h}$ to reach a confluency of greater than 50\%. SNPs were diluted in EMEM medium to a final concentration of $0.1 \mathrm{mg} \mathrm{mL}^{-1}$ and were sonicated for approximately $15 \mathrm{~min}$ prior to all experiments.
The cells were then treated with $\left\{\mathrm{Mo}_{6} \mathrm{I}_{8}\right\} @ \mathrm{SiO}_{2}$ in culture medium for $0,0.25,0.5,1,2,4$ and $8 \mathrm{~h}$ at $37{ }^{\circ} \mathrm{C}$ under a $5 \% \mathrm{CO}_{2}$ atmosphere. After treatment, cells were rinsed three times with ice cold phosphate buffered saline (PBS) to remove any free SNPs. Cells were then trypsinized and resuspended in fresh PBS with $10 \%$ FBS.

Cell suspensions were analysed using a FACSCanto II (Becton Dickinson, USA). A $488 \mathrm{~nm}$ excitation source was used with a $695 \mathrm{~nm}$ emission filter. Gating was utilised using a negative sample and the data were expressed as the median fluorescence intensity. All of the data were the mean fluorescence obtained from a population of 10000 cells.

\section{Cellular elimination kinetics}

Hep-2 cells were seeded in 6-well plates at $3 \times 10^{5}$ cells per well for each time point $(0,0.25,0.5,1,2,4$ and $24 \mathrm{~h})$ and were incubated for $24 \mathrm{~h}$ to reach a confluency of greater than $50 \%$. $\left\{\mathrm{Mo}_{6} \mathrm{I}_{8}\right\} @ \mathrm{SiO}_{2}$ was diluted in EMEM medium to a final concentration of $0.1 \mathrm{mg} \mathrm{mL} \mathrm{mL}^{-1}$ and was sonicated for approximately 15 min prior to all experiments. The cells were then exposed to $\left\{\mathrm{Mo}_{6} \mathrm{I}_{8}\right\} @ \mathrm{SiO}_{2}$ in culture medium for $2 \mathrm{~h}$ at $37{ }^{\circ} \mathrm{C}$ under a $5 \% \mathrm{CO}_{2}$ atmosphere. After treatment, the medium containing SNPs was then replaced with a fresh medium and cells were incubated for $0.25,0.5,1,2,4$ and $24 \mathrm{~h}$. Cells were then trypsinized and resuspended in fresh PBS with 10\% FBS.

Cell suspensions were analysed using a FACSCanto II (Becton Dickinson, USA). A $488 \mathrm{~nm}$ excitation source was used with a $695 \mathrm{~nm}$ emission filter. Gating was utilised using a negative sample and the data were expressed as the median fluorescence intensity. All of the data were the mean fluorescence obtained from a population of 10000 cells.

\section{Confocal laser scanning microscopy}

Hep-2 cells were seeded on slides $\left(1.5 \times 10^{5}\right.$ cells per slide $)$ and incubated overnight at $37{ }^{\circ} \mathrm{C}$ under a $5 \% \mathrm{CO}_{2}$ atmosphere. The medium was then replaced with a fresh medium containing $0.1 \mathrm{mg} \mathrm{mL}{ }^{-1}$ of $\left\{\mathrm{Mo}_{6} \mathrm{I}_{8}\right\} @ \mathrm{SiO}_{2}$ and incubated for $24 \mathrm{~h}$. The cells incubated in the absence of SNPs were used as a control. Finally, the cells were washed twice with PBS, fixed in $4 \%$ paraformaldehyde, and washed thrice with PBS. Cells were visualised by using a Zeiss LSM 510 confocal microscope (Carl Zeiss Inc., Jena, Germany) equipped with a laser diode $(405 \mathrm{~nm})$ for fluorescence and with a $100 \times$ oil immersion objective. The images were obtained and analysed using ZEN 2009 software. Each experiment was repeated three times on separate days.

\section{Transmission electron microscopy (TEM)}

Hep-2 cells were grown in a $25 \mathrm{~cm}^{2}$ culture flask $\left(6 \times 10^{5}\right.$ cells per flask) for $24 \mathrm{~h}$, after which the cells were exposed to $0.1 \mathrm{mg} \mathrm{mL}$ of SNPs for $24 \mathrm{~h}$. Cells were washed with PBS and trypsinized. Then $1 \mathrm{~mL}$ medium containing $1 \times 10^{6}$ cells was pipetted into BEEM capsules. Cells were centrifuged at $1000 \mathrm{~g}$ for $5 \mathrm{~min}$ at room temperature to form a pellet at the bottom of the capsule. The cells were fixed with $2 \%$ glutaraldehyde in PBS for $2 \mathrm{~h}$, followed by two 30 min PBS washes. 1\% osmium tetroxide in PBS $(1 \mathrm{~mL})$ was added to the fixed cell pellet for $1 \mathrm{~h}$. Then the samples 
were treated according to the general protocols for TEM. The full protocol was previously described by Schrand et al. ${ }^{51}$ The ultrathin sections $(70 \mathrm{~nm})$ without additional staining by uranyl acetate and lead citrate were viewed on a Libra 120 (Zeiss) TEM operating at $120 \mathrm{kV}$. Energy-filtered transmission electron microscopy (EFTEM) elemental maps were recorded using the standard three window technique described in Brydson, Electron Energy Loss Spectroscopy, BIOS: Oxford (2001).

\section{Evaluation of the photodynamic cytotoxicity}

The Hep-2 cells were seeded in 96-well plates at the density of $5 \times 10^{3}$ cells per well and cultured for $24 \mathrm{~h}$. The medium was then replaced with the fresh medium containing from 0.0125 to $0.22 \mathrm{mg} \mathrm{mL}{ }^{-1}$ of neat $\mathrm{SiO}_{2}$ and $\left\{\mathrm{Mo}_{6} \mathrm{I}_{8}\right\} @ \mathrm{SiO}_{2}$, incubated for $2 \mathrm{~h}$ and then irradiated by a $500 \mathrm{~W}$ halogen lamp $(\lambda \geq 400 \mathrm{~nm})$ for $30 \mathrm{~min}$ to apply a total light dose of $20 \mathrm{~J} \mathrm{~cm}^{-2}$. The photosensitiser for the positive control (Radachlorin ${ }^{\circledR}$ ) was purchased from the RADA-PHARMA group (RADA-PHARMA Co, Ltd, Moscow, Russia). Radachlorin was used at concentrations typical for in vitro studies $\left(0.0025-0.1 \mathrm{mg} \mathrm{mL}{ }^{-1}\right) .{ }^{45}$ Cells cultured in the medium without SNPs served as a negative control. The viability of treated and control cells was assayed and analysed $24 \mathrm{~h}$ later using viability, apoptosis and proliferation assay as described above.

\section{Statistical analysis}

Statistical analyses were performed using the Mann-Whitney $U$ test for unpaired data and $P$ values of less than 0.01 were considered as significant. Data are presented as mean \pm SEM (standard error of the mean).

\section{Conclusions}

In this work, we established that SNPs doped by photoluminescent molybdenum cluster $\left\{\mathrm{Mo}_{6} \mathrm{I}_{8}\right\}^{4+}$ had low cellular toxicity in the darkness and high biocompatibility. In the similar manner as neat SNPs, photoluminescent SNPs rapidly entered the cells (presumably via endocytosis) and remained in the cytoplasm for a long time. Internalised into Hep-2 cells, particles showed significant photoluminescence in the red region even after maximal elimination, as it was demonstrated by confocal imaging and FACS studies. Experiments on photoirradiation of the cells incubated with $\left\{\mathrm{Mo}_{6} \mathrm{I}_{8}\right\} @ \mathrm{SiO}_{2}$ nanoparticles unambiguously showed high photoinduced cellular toxicity of the materials. Moreover, particles with the higher loading of the metal cluster were more toxic to Hep-2 cells upon photoirradiation.

Consequently, we suggest that photoluminescent $\left\{\mathrm{Mo}_{6} \mathrm{I}_{8}\right\}$ @ $\mathrm{SiO}_{2}$ nanoparticles have good potential for applications in in vitro bioimaging and cellular photosensitisation, studies on oxidative stress, or PDT. Therefore, the future research will focus on the ways to further improve the PLQYs of the hybrid materials by, for example, developing and immobilisation of labile/non-labile mixed-ligand cluster complex precursors and the surface functionalisation of the particles by specific ligands and/or biological cargos.

\section{Acknowledgements}

We are grateful to the Russian Science Foundation for funding (Grant No. 14-14-00192), and to the Microscopic Centre of the Siberian Branch of the Russian Academy of Sciences for granting access to microscopic equipment. Dr O. A. Efremova thanks the University of Hull for the academic starting grant.

\section{Notes and references}

1 S. Cordier, F. Grasset, Y. Molard, M. Amela-Cortes, R. Boukherroub, S. Ravaine, M. Mortier, N. Ohashi, N. Saito and H. Haneda, J. Inorg. Organomet. Polym. Mater., 2015, 25, 189-204.

2 J. Elistratova, M. Mikhailov, V. Burilov, V. Babaev, I. Rizvanov, A. Mustafina, P. Abramov, M. Sokolov, A. Konovalov and V. Fedin, RSC Adv., 2014, 4, 27922-27930.

3 J. Elistratova, V. Burilov, A. Mustafina, M. Mikhailov, M. Sokolov, V. Fedin and A. Konovalov, Polymer, 2015, 72, 98-103.

4 M. N. Sokolov, M. A. Mihailov, E. V. Peresypkina, K. A. Brylev, N. Kitamura and V. P. Fedin, Dalton Trans., 2011, 40, 6375-6377.

5 K. Kirakci, P. Kubat, M. Dusek, K. Fejfarova, V. Sicha, J. Mosinger and K. Lang, Eur. J. Inorg. Chem., 2012, 3107-3111.

6 K. Kirakci, P. Kubat, J. Langmaier, T. Polivka, M. Fuciman, K. Fejfarova and K. Lang, Dalton Trans., 2013, 42, 7224-7232.

7 K. Kirakci, K. Fejfarova, M. Kucerakova and K. Lang, Eur. J. Inorg. Chem., 2014, 2331-2336.

8 K. Kirakci, V. Sicha, J. Holub, P. Kubat and K. Lang, Inorg. Chem., 2014, 53, 13012-13018.

9 M. N. Sokolov, M. A. Mikhailov, A. V. Virovets, K. A. Brylev, R. A. Bredikhin, A. M. Maksimov, V. E. Platonov and V. P. Fedin, Russ. Chem. Bull., 2013, 62, 1764-1767.

10 M. N. Sokolov, M. A. Mikhailov, K. A. Brylev, A. V. Virovets, C. Vicent, N. B. Kompankov, N. Kitamura and V. P. Fedin, Inorg. Chem., 2013, 52, 12477-12481.

11 O. A. Efremova, M. A. Shestopalov, N. A. Chirtsova, A. I. Smolentsev, Y. V. Mironov, N. Kitamura, K. A. Brylev and A. J. Sutherland, Dalton Trans., 2014, 43, 6021-6025.

12 M. A. Mikhailov, K. A. Brylev, A. V. Virovets, M. R. Gallyamov, I. Novozhilov and M. N. Sokolov, New J. Chem., 2016, 40, 1162-1168.

13 L. Riehl, M. Strövele, D. Enseling, T. Jüstel and H.-J. Meyer, Z. Anorg. Allg. Chem., 2016, 642, 403-408.

14 R. Weissleder, Nat. Biotechnol., 2001, 19, 316-317.

15 O. A. Efremova, K. A. Brylev, Y. A. Vorotnikov, L. Vejsadová, M. A. Shestopalov, G. F. Chimonides, P. D. Topham, N. Kitamura and A. J. Sutherland, J. Mater. Chem. C, 2016, 4, 497-503.

16 J. A. Jackson, M. D. Newsham, C. Worsham and D. G. Nocera, Chem. Mater., 1996, 8, 558-564.

17 J. A. Jackson, C. Turro, M. D. Newsham and D. G. Nocera, J. Phys. Chem., 1990, 94, 4500-4507.

18 K. Kirakci, P. Kubát, K. Fejfarova, J. Martincik, M. Nikl and K. Lang, Inorg. Chem., 2016, 55, 803-809. 
19 P. Agostinis, K. Berg, K. A. Cengel, T. H. Foster, A. W. Girotti, S. O. Gollnick, S. M. Hahn, M. R. Hamblin, A. Juzeniene, D. Kessel, M. Korbelik, J. Moan, P. Mroz, D. Nowis, J. Piette, B. C. Wilson and J. Golab, Ca-Cancer J. Clin., 2011, 61, 250-281.

20 A. P. Castano, P. Mroz and M. R. Hamblin, Nat. Rev. Cancer, 2006, 6, 535-545.

21 D. E. J. G. J. Dolmans, D. Fukumura and R. K. Jain, Nat. Rev. Cancer, 2003, 3, 380-387.

22 T. J. Dougherty, C. J. Gomer, B. W. Henderson, G. Jori, D. Kessel, M. Korbelik, J. Moan and Q. Peng, J. Natl. Cancer Inst., 1998, 90, 889-905.

23 A. A. Krasilnikova, M. A. Shestopalov, K. A. Brylev, I. A. Kirilova, O. P. Khripko, K. E. Zubareva, Y. I. Khripko, V. T. Podorognaya, L. V. Shestopalova, V. E. Fedorov and Y. V. Mironov, J. Inorg. Biochem., 2015, 144, 13-17.

24 T. Aubert, F. Cabello-Hurtado, M. A. Esnault, C. Neaime, D. Lebret-Chauvel, S. Jeanne, P. Pellen, C. Roiland, L. Le Polles, N. Saito, K. Kimoto, H. Haneda, N. Ohashi, F. Grasset and S. Cordier, J. Phys. Chem. C, 2013, 117, 20154-20163.

25 K. Kirakci, P. Kubát, M. Kučeráková, V. Šícha, H. Gbelcová, P. Lovecká, P. Grznárová, T. Ruml and K. Lang, Inorg. Chim. Acta, 2016, 441, 42-49.

26 N. A. Vorotnikova, O. A. Efremova, A. R. Tsygankova, K. A. Brylev, M. V. Edeleva, O. G. Kurskaya, A. J. Sutherland, A. M. Shestopalov, Y. V. Mironov and M. A. Shestopalov, Polym. Adv. Technol., 2016, 27, 922-928.

27 K. Y. Choi, G. Liu, S. Lee and X. Y. Chen, Nanoscale, 2012, 4, 330-342.

28 S. J. Choi, K. A. Brylev, J. Z. Xu, Y. V. Mironov, V. E. Fedorov, Y. S. Sohn, S. J. Kim and J. H. Choy, J. Inorg. Biochem., 2008, 102, 1991-1996.

29 M. A. Shestopalov, K. E. Zubareva, O. P. Khripko, Y. I. Khripko, A. O. Solovieva, N. V. Kuratieva, Y. V. Mironov, N. Kitamura, V. E. Fedorov and K. A. Brylev, Inorg. Chem., 2014, 53, 9006-9013.

30 G. Pilet, S. Cordier, S. Golhen, C. Perrin, L. Ouahab and A. Perrin, Solid State Sci., 2003, 5, 1263-1270.

31 K. A. Brylev, Y. V. Mironov, V. E. Fedorov, S.-J. Kim, H.-J. Pietzsch, H. Stephan, A. Ito and N. Kitamura, Inorg. Chim. Acta, 2010, 363, 2686-2691.

32 K. A. Brylev, Y. V. Mironov, S. G. Kozlova, V. E. Fedorov, S.-J. Kim, H.-J. Pietzsch, H. Stephan, A. Ito, S. Ishizaka and N. Kitamura, Inorg. Chem., 2009, 48, 2309-2315.
33 A. Gandubert, K. A. Brylev, T. T. Nguyen, N. G. Naumov, N. Kitamura, Y. Molard, R. Gautier and S. Cordier, Z. Anorg. Allg. Chem., 2013, 639, 1756-1762.

34 F. Grasset, F. Dorson, S. Cordier, Y. Molard, C. Perrin, A. M. Marie, T. Sasaki, H. Haneda, Y. Bando and M. Mortier, Adv. Mater., 2008, 20, 143-148.

35 Y. A. Vorotnikov, O. A. Efremova, N. A. Vorotnikova, K. A. Brylev, M. V. Edeleva, A. R. Tsygankova, A. I. Smolentsev, N. Kitamura, Y. V. Mironov and M. A. Shestopalov, RSC Adv., 2016, 6, 43367-43375.

36 K. J. Cho, X. Wang, S. M. Nie, Z. Chen and D. M. Shin, Clin. Cancer Res., 2008, 14, 1310-1316.

37 W. H. De Jong and P. J. A. Borm, Int. J. Nanomed., 2008, 3, 133-149.

38 M. Gaumet, A. Vargas, R. Gurny and F. Delie, Eur. J. Pharm. Biopharm., 2008, 69, 1-9.

39 I.-Y. Kim, E. Joachim, H. Choi and K. Kim, Nanomedicine, 2015, 11, 1407-1416.

40 Y. H. Jin, S. Kannan, M. Wu and J. X. J. Zhao, Chem. Res. Toxicol., 2007, 20, 1126-1133.

41 J. C. Sheldon, Nature, 1959, 184, 1210-1213.

42 A. Lesniak, F. Fenaroli, M. P. Monopoli, C. Aberg, K. A. Dawson and A. Salvati, ACS Nano, 2012, 6, 5845-5857.

43 K. Shapero, F. Fenaroli, I. Lynch, D. C. Cottell, A. Salvati and K. A. Dawson, Mol. BioSyst., 2011, 7, 371-378.

44 I. M. Adjei, B. Sharma and V. Labhasetwar, Nanomaterials, 2014, 811, 73-91.

45 H. Mirzaei, G. E. Djavid, M. Hadizadeh, M. JahanshiriMoghadam and P. Hajian, J. Photochem. Photobiol., B, 2015, 142, 86-91.

46 E. V. Kochneva, E. V. Filonenko, E. G. Vakulovskaya, E. G. Scherbakova, O. V. Seliverstov, N. A. Markichev and A. V. Reshetnickov, Photodiagn. Photodyn. Ther., 2010, 7, 258-267.

47 W. Ji, J.-W. Yoo, E. K. Bae, J. H. Lee and C.-M. Choi, Photodiagn. Photodyn. Ther., 2013, 10, 120-126.

48 L. Prasmickaite, A. Høgset, P. K. Selbo, B. Ø. Engesæter, M. Hellum and K. Berg, Br. J. Cancer, 2002, 86, 652-657.

49 P. K. Selbo, A. Weyergang, A. Høgset, O.-J. Norum, M. B. Berstad, M. Vikdal and K. Berg, J. Controlled Release, 2010, 148, 2-12.

50 Y. Lee and E. Shacter, J. Biol. Chem., 1999, 274, 19792-19798. 51 A. M. Schrand, J. J. Schlager, L. Liming Dai and S. M. Hussain, Nat. Protoc., 2010, 5, 744-757. 